矤器学 Vol. 62, Suppl. (1992)

38. 腹胿鏡下手術における結紮補助器具の作成

日本大学医学部第三外科

岩井重富, 国松正彦, 須田清美, 山形基夫, 笠倉雄一 宋圭男, 望月文朗, 山形佳香, 水野泰彦, 加澤玉恵 張 遠春, 田中 隆

うしお病院

宇治田弘一, 潮 沙都也

はじめに

腹部外科領域においては腹腔鏡下での手術 が急速に広まりつつある。本法は術後の疼痛 がほとんどなく，術創も軽微で患者にとって 非常に有益である。しかし多くの手術器具を 必要とし, 今後多くの器具, 術式の改良が必 要である。腹腔鏡下手術における結热補助器 具の作成と同法による胆震摘出術での術中造 影での工夫について記载する。

\section{1. 結禁補助器具の作成}

腹沿鏡下手術では現在のところ, 胆霖摘出 術が最も多く行なわれており, 我々も 70 症 例以上の胆露摘出術を経験している。炎症所 見が軽度の症例では胆震胆管, 胆露動脈の処 理は通常エンドクリップで行なっているが， 中等度以上の炎症のおった症例では, 胆露胆 管の肥厚が強く, クリッピングが不可能のも のもある。鉗子を用いての腹腔内結禁操作は 意外に繁雑であり，かなりの熟練を要する。 このような場合，一般的にエンドループが使 用されているが, 胆道造影時の造影剤漏れ防 止用の結禁には応用できない。そのため初心 者でも容易に処理出来るよう結禁補助器具を 作成した。本器具は目的部に結热系を通し, 腹腹外で作った結び目を腹腔内に送りこむも ので, 結紮処理が確実である(図 1)。本 器具は経 $4 \mathrm{~mm}$, 長さ約 $35 \mathrm{~cm}$ の金属製の桿で, 先端部に結び目を送りこむための約 $0.5 \mathrm{~mm} の$ 細溝を刻んだものである（図 2）。 本器具と同样の目的のものが米国では市販さ れているが（図 3），先端部分が小さな馬 蹄形状となっており，結び目が送りこまれる 時に摩擦が大きく，サージポート内で固定さ れてしまう場合もある。我々は先端部を種々 の形状に作成し，結柇操作を試みた結果，摩 擦が少なくスムーズな結禁が可能となった。 これは先端部に0.5mmの細满を施し，この型を スムーズに湾曲させたむのである。これによ り結勢操作が非常に容易となった（図 4)。
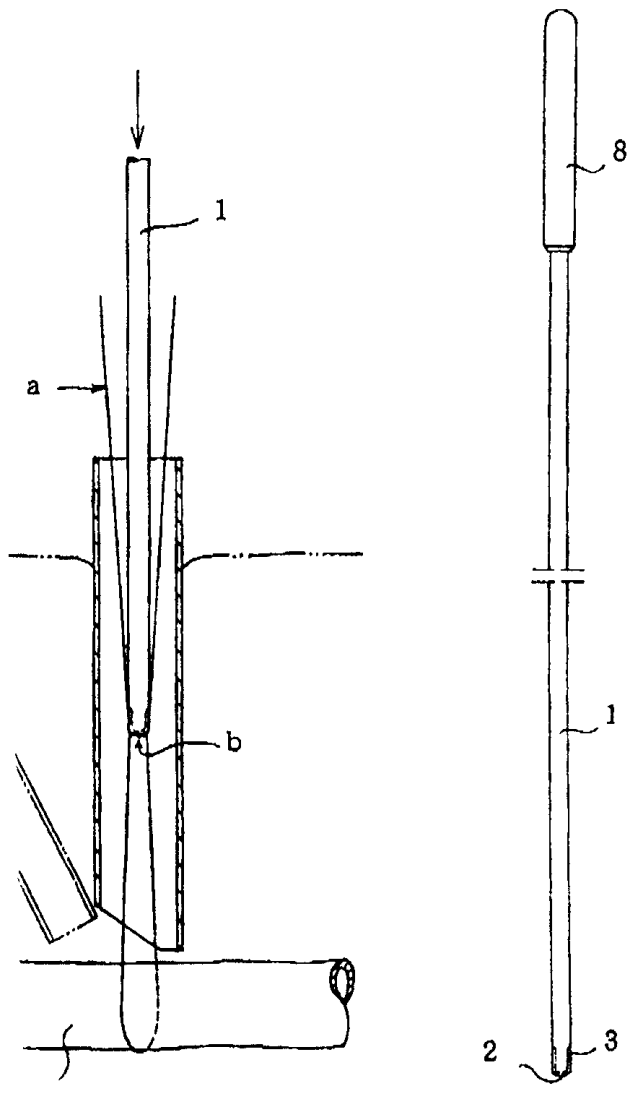

娄 1

国 2

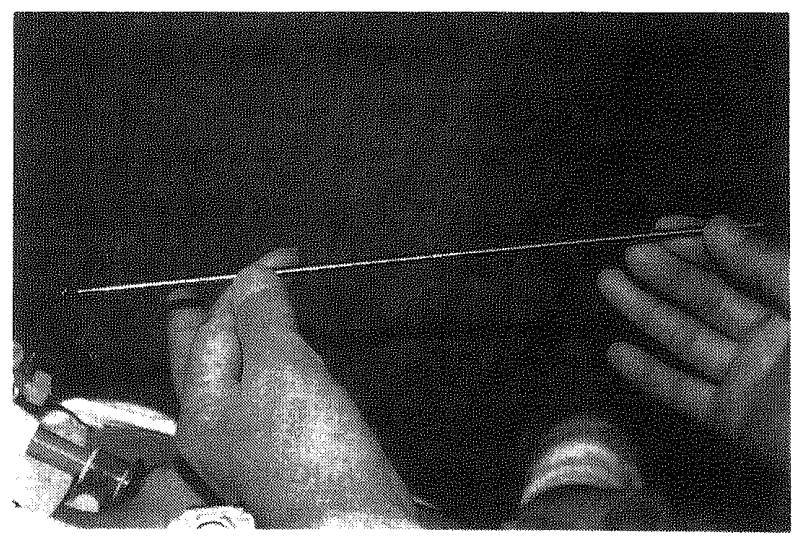

図 3 
本器具は胆露胆管，胆震動脈を結䇣する場合 に非常に有用であるが, その他に出血部位の 結等，胆震呀孔時の閉鎖にも用いることがて きる。また，腹䶼鏡下手術のみならず通常の 開腹，開胸手術時の梁部での結禁のために， 約 $15 \mathrm{~cm}$ の長さに作成して一般手術での态用を 試みている。

2 . 腹腔鏡下胆道造影の工夫

腹胿鏡下胆道造影は同胆豪摘出術の安全性 の保持に重要である。現在のところ, 胆道造 影用クランプ鉗子が多く用いられているが， 一部の施設では入手困難なところむある。 我々はエビニード硬膜外針（TERUM0）(図 5) および同持続麻酔カテーテルを用いて良好な 結果を得ている。まず，同硬膜外針を胆震胆 管直上部腹壁より穿刺する（図 6)。同針 先端部を胆管切開孔に㨉入し, 切開孔を搪大 し, 約 $1-2 \mathrm{~mm}$ 間隔をおいて稢える。同カテー テル先端部的 $4 \mathrm{~cm}$ にはマークがなくこれを切 離すると，先端より $1 \mathrm{~cm} こ と$ 黒色マークが 認められる。これを硬膜外針より挿入する。 この間, カテーテルより随時生食液を注入し 切開孔を明瞭にする。切開孔よりカテーテル が挿入されると捜入深度がマークにより明ら かとなる。㨂入梁度を約 $1-2 \mathrm{~cm} に と と ゙ め て ，$ エンドクリッブにて固定するが，この際生食 液を注入しながら行い，注入にやや抵抗が感 じられたらクリッビング操作をとどめる。以 後，造影は容易に行なわれる。PTC針（八光） についても同様である。以下に本法の長所を 列記する。

1)同針はディスボーザブルで入手が容易である。

2)非常に軽量でカテーテル㨂人が容易である。

3)腹热鏡用の鉗子孔を使用せず，自由に穿刺 部位を設定出来る。

4)位置を变更しての再穿刺も可能である。

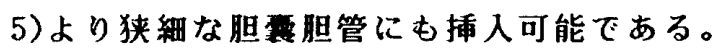

6)針を抜去後に撮影可能で，映像の妨げにな

らない。

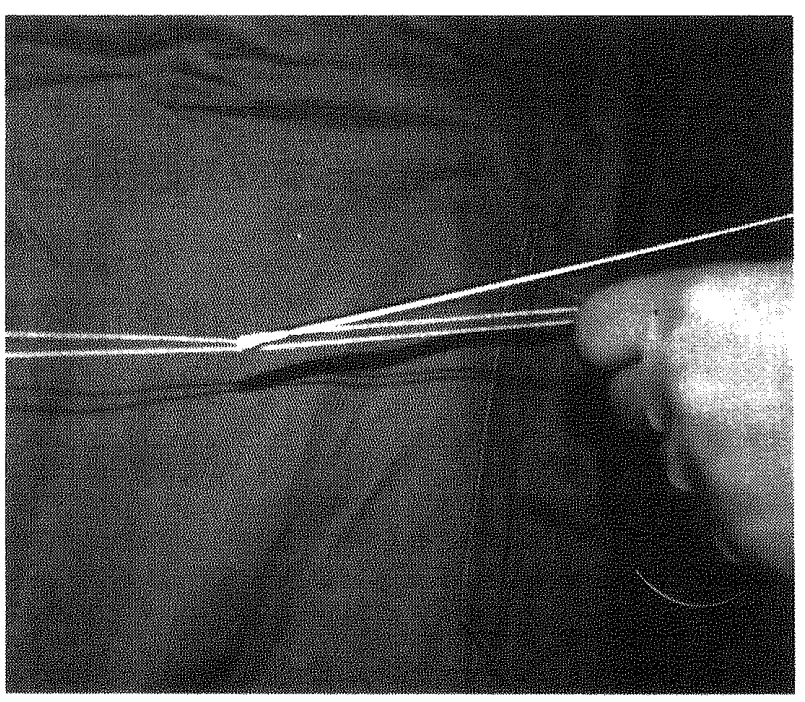

図 4

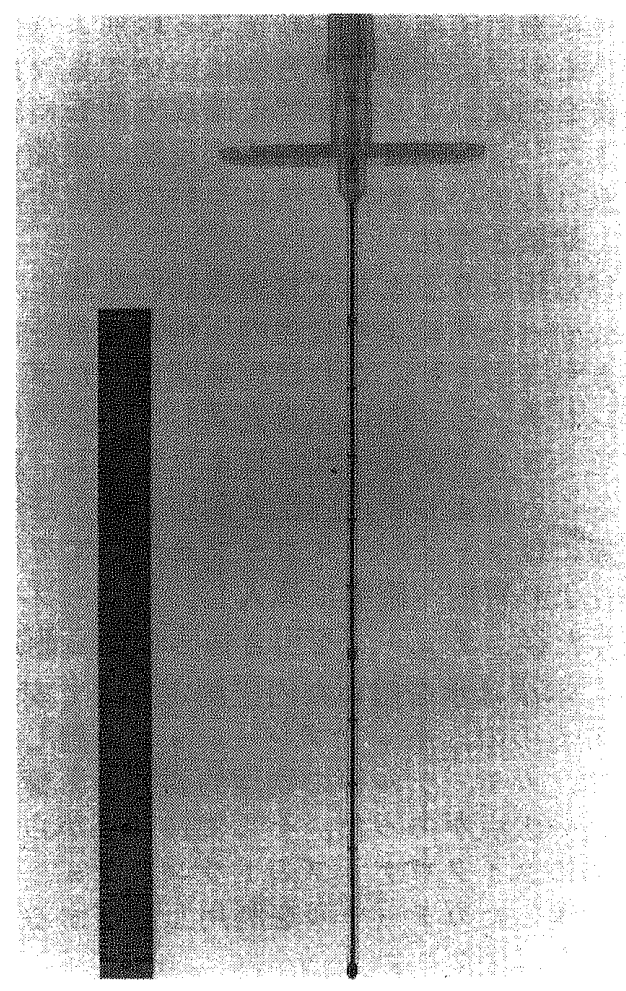

图 5

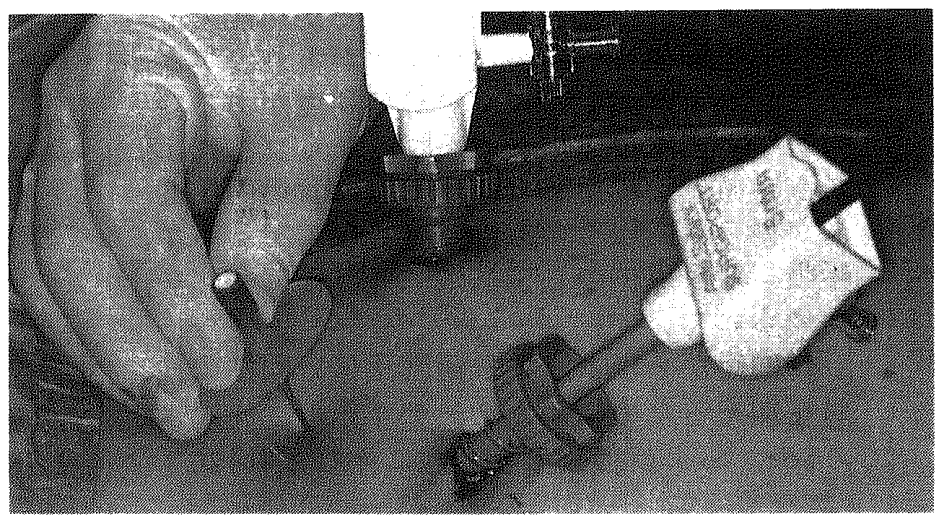

